Selcuk Journal of Agriculture and Food Sciences

http://sjafs.selcuk.edu.tr/sjafs/index

Research Article
SJAFS

(2020) 34 (2), 154-161

e-ISSN: 2458-8377

DOI:10.15316/SJAFS.2020.210

\title{
Determination of Some Agronomic Traits and Their Correlation with Yield Components in Cowpea
}

\author{
(D)Mustafa CERITOGLU ${ }^{1, *}$, (D)Murat ERMAN ${ }^{1}$ \\ ${ }^{1}$ Siirt University, Faculty of Agriculture, Department of Field Crops, Siirt, Turkey
}

\begin{tabular}{l}
\hline ARTICLE INFO \\
\hline Article history: \\
Received date: 29.05 .2020 \\
Accepted date: 26.06 .2020 \\
\hline Edited by: \\
Ali KAHRAMAN; Selçuk \\
University, Turkey \\
Reviewed by: \\
Mustafa ÖNDER; SelçukUniversity, \\
Turkey \\
Ömer SÖZEN; Kirşehir Ahi Evran Uni- \\
versity, Turkey \\
\hline
\end{tabular}

Keywords:

Adaptation

Agronomic traits

Chlorophyll (SPAD-502)

Correlation

Heat stress

Vigna unguiculata

\section{Introduction}

Food legumes play a significant and diverse role in the farming systems and the diets of poor people around the World (Stoilova, Pereira, Sousa and Carnide, 2005). Cowpea, Vigna unguiculata, is considered an essential grain legume adapted to sub-Saharan Africa (SSA) where it supplies to the nutrition, health, and income of rural and suburban inhabitants (Boukar et al., 2015).

Cowpea is the most produced grain legume on the World after common bean and chickpea. Additionally, due to its high nutritional value, cowpea is one of the most important legumes for indigenous Africa (Agbicodo, Fatokun, Muranaka, Visser et al., 2009). Cowpea seed contains $24.8 \%$ protein, $1.9 \%$ lipid, $6.3 \%$ fiber, $63.6 \%$ carbohydrate, ash, riboflavin, carotene and vitamin B1 (Stancheva et al., 2016). Generally, the production and consumption of cowpea is high in the world, Although, it is lower than other grain legumes in the Turkish market. The cowpea production area was nearly 12.5 million

\footnotetext{
*Corresponding author email: ceritoglu@siirt.edu.tr
}

hectares in the World while it was produced in 13.5 thousand hectares in Turkey in 2018 (Food and Agriculture Organization of the United Nations [FAO], 2018; Türkiye İstatistik Kurumu [TUIK], 2018). The main reasons for the low production of cowpea in Turkey are low demand, lack of export opportunities and low grain yield per unit area and farmers turning to more profitable crops (Sert and Ceyhan, 2012).

Some problems occur in common bean cultivation in regions such as Southeastern Anatolia, where temperatures are high and precipitation is very low during the summer season (Sozen and Karadavut, 2017). High temperature has negative effects on plant growth and grain yield in common bean (Kazai, Noulas, Khah and Vlachostergios, 2019). However, cowpea can be easily grown in drought and subtropic regions. Incorporating to hot and dry conditions and minimal soil selectivity are the main reasons for the spread of cowpea cultivation worldwide (Kahraman, 2017; Simion, 2018). Cowpea generally favors hot climate and shows optimum growth in regions in which average temperatures are nearly $25^{\circ} \mathrm{C}$ in summer (Boukar et al., 2015). 
Cowpea is an important rotation crop. It forms a symbiosis with appropriate Rhizobium bacteria similar to other legumes. Despite the important role acted by biological Nitrogen fixation, little is known of the symbiosis between cowpea varieties and native or recommended Rhizobium spp. (Freitas, Silva and Sampaio, 2012). So, it provides more productive soil for the next seasons' plant (Sanchez-Navarro, Zornoza, Faz and Fernandez, 2019). The values are vary depending on the genotypic variation and ecological conditions (Makoi, Chimphango and Dakora, 2009). Moreover, due to their taproot system, cowpea allows aeration in the soil for a more productive and fertile rhizosphere in rotation systems. Simunji, Munyinda, Lungu and Mweetwa (2019) suggested that cowpea provides to improve yield on the second crop in rotation.

This is of concern due to the ecological constraints of the Southeast Anatolian region, the number of crop species adapted to local harsh climate is limited. Region's agriculture and farmers need novel products that have high adaptation potential and added-value. Cover crops in the region are exposed to strong heat stress and almost no rain in summer seasons (Table 2). Many crops can not cope with these ecological conditions. In all but few genera are negatively affected due to high temperature and drought conditions. Therefore, researching new plants that can be grown in the region is a need. The aim of this study was to understand different agronomic variations of various cowpea genotypes and their correlation with yield and yield components in semi-arid and high temperature conditions.

\section{Materials and Methods}

\subsection{Study Site and Location}

The study was conducted in Siirt University in 2019. The city where the study was laid out is located on $41^{\circ} 57^{\prime}$ east longitude and $37^{\circ} 55^{\prime}$ north latitude, Southeastern Anatolia Region of Turkey. The altitude of the city is $880 \mathrm{~m}$.

\subsection{Plant Materials and Experimental Design}

Table 2

Some climate data belonging on area

\begin{tabular}{|c|c|c|c|c|c|c|}
\hline \multirow[b]{2}{*}{ Months } & \multicolumn{2}{|c|}{$\begin{array}{l}\text { Rainfall } \\
(\mathrm{mm})\end{array}$} & \multicolumn{2}{|c|}{$\begin{array}{c}\text { Average } \\
\text { Temperature }\left({ }^{\circ} \mathrm{C}\right)\end{array}$} & \multicolumn{2}{|c|}{$\begin{array}{c}\text { Relative } \\
\text { humidity (\%) }\end{array}$} \\
\hline & 2019 & $\begin{array}{c}\text { Long Years } \\
\text { Average }\end{array}$ & 2019 & $\begin{array}{l}\text { Long Ye- } \\
\text { ars Avera- } \\
\text { ge }\end{array}$ & 2019 & $\begin{array}{l}\text { Jong Years } \\
\text { Average }\end{array}$ \\
\hline March & 182.0 & 92.3 & 8.3 & 10.1 & 63.5 & 59.2 \\
\hline April & 175.6 & 91.7 & 11.9 & 15.3 & 66.8 & 53.8 \\
\hline May & 64.4 & 69.5 & 21.9 & 20.0 & 41.8 & 49.6 \\
\hline June & 1.2 & 10.8 & 29.1 & 27.0 & 26.5 & 28.7 \\
\hline July & 2.0 & 2.6 & 31.8 & 31.7 & 19.9 & 20.4 \\
\hline August & 1.4 & 1.9 & 32.0 & 31.6 & 19.3 & 19.6 \\
\hline Total & 427 & 269 & & & & \\
\hline Mean & & & 22.5 & 22.6 & 39.6 & 38.6 \\
\hline
\end{tabular}

In the study, 3 cultivars (Karagöz-86, Karnıkara and Akkiz) supplied from a commercial company and 3 local populations $\left(\mathrm{L}_{1}, \mathrm{~L}_{2}\right.$ and $\left.\mathrm{L}_{3}\right)$ collected from the Tokat, Samsun and Manisa regions were adopted. The cultivars used in the study are the most growth cowpea varieties in Turkey. The local populations are grown in different regions of Turkey and exhibit hopeful performance.

The study was laid out in a randomized complete block design with 4 replications. The plots were constituted as 4 rows and $9.6 \mathrm{~m}^{2}(0.6 \times 4) \times 4$. Row spacing and Intra-row distances were determined as $60 \mathrm{~cm}$ and $10 \mathrm{~cm}$, respectively (Augustine, 2018).

\subsection{Soil Analysis and Climatic Traits}

According to Table 1, the soil of the trial area was composed of deep and medium-deep soil which is low in organic matter and phosphorus content, enough in potassium. Also, it was a little saline and limy. The texture of soil was clay loam, $\mathrm{pH}$ was alkaline near neutral (FMANR, 1990). Based on reference soil analysis results, $4 \mathrm{~kg} / \mathrm{da}$ Diammonium phosphate was applied with sowing under the seed drill (Daramy, Sardoie-Addo and Dumbuya, 2016). Irrigation was done with a drip system. Weed control was realized with mechanical methods, not any chemical.

Table 1

Properties of soil in the study area

\begin{tabular}{lc}
\hline Deepth (cm) & $0-20$ \\
Structure (Sand: Silt: Clay) (\%) & $39: 6.3: 54.6$ \\
pH & 7.5 \\
EC (dS/cm) & 6.64 \\
Lime (\%) & 9.3 \\
Organic matter (\%) & 1.4 \\
Phosphorus (kg/da) & 1.91 \\
Potassium (kg/da) & 149 \\
\hline
\end{tabular}

The region has characteristic temperature and humidity of the terrestrial climate. Temperature and humidity values of vegetation period were similar to the long years' average ranges. However, the rainfall was erratic and excessive compared with the long years average. Some climate data were given in Table 2. 


\subsection{Measurement of Traits}

All traits investigated on 10 plants collected from per plot. Plant height $(\mathrm{PH})$, number of pods per plant (NP), number of seeds per plant (NS) and seed yield (SY) were measured according to Erman and Çı̆ (2009). The Stem diameter (SD) was measured at 1 $\mathrm{cm}$ above the soil surface with an electronic digital caliper (Mitutoyo 500-182-30 digital caliper, Co. Ltd., Japan) (Verbree, Singh and Payne, 2015). Leaf surface temperature (LST) was measured with an infrared thermometer (SATO SK-8700, Co. Ltd., South Korea) with a $45^{\circ}$ angle and $10 \mathrm{~cm}$ distance to the leaf surface on a clear day between 12.00-14.00 during the flowering time $(\mathrm{Yu}$, Wang, Xin and Zheng., 2016). Total chlorophyll content (TCC) of the leaf was measured with portable chlorophyll meter (SPAD-502, Minolta Camera Co. Ltd., Japan) on the upper fully expanded leaf at the beginning of flowering (Dong et al., 2019).

\subsection{Statistical Analysis}

The Shapiro-Wilk test was applied to evaluate the normality of data (Korkmaz et al., 2014). Data were calculated by analysis of variance in the $R$ v.3.5.2 according to the randomized complete block design. The results were grouped according to the TUKEY test (Mangiafico, 2016). According to the results of multiple comparisons, significant differences $(P<0.01)$ were determined between genotypes for all traits except leaf surface temperature. The correlation analysis of all the characters was calculated as per the procedure stated by Al-jubouri, Millar and Robinson (1958).

\section{Results and Discussion}

\subsection{Agronomic traits}

According to the results, cv. Karagöz had superior traits compared to others and it exhibited more tolerance in heat condition. PH, SD, LST, TCC changed between 54.6-91.3 cm, 3.1-7.6 mm, 27.9$31.7^{\circ} \mathrm{C}, 39-56.1 \%$, respectively (Table 4 ).

\subsubsection{Plant height}

The highest PH was determined in Karagöz (92.3 $\mathrm{cm})$ while the shortest one $(54.6 \mathrm{~cm})$ was observed in $\mathrm{L}_{2}$ (Table 3). However, the difference between $\mathrm{L}_{2}$ and $\mathrm{L}_{3}$ landraces was not significant. Different researchers reported that $\mathrm{PH}$ in cowpea changes between 27.9-108.5 cm (El-Naim, Jabereldar, Ahmed, Ismaeil et al., 2012; Bisikwa et al., 2014). Also, Massey, Singh, Nautiyal and Bhatt (2020) stated that PH is genotype-dependent and changes week by week during the growth period. Therefore, the adaptation potential of genotype to the environment has a vital role in $\mathrm{PH}$.

\subsubsection{Stem diameter}

The thickest SD was in Karagöz while the thinnest one was in $\mathrm{L}_{3}$ landrace (Table 4). According to these results, SD had a significant variation among genotypes. Verbree et al. (2015) stated that stem diameter, which is an important and easy phenotypic trait, may also be an indicator of response to drought stress in cowpea. Also, thicker stem in plants provides resistance them to lodging which is a vital reason for death in seedlings. Previous reports showed similarities with the result in this study. Ravelombola et al. (2018) stated that stem diameter value in cowpea affected by drought changed between 2.45 $3.69 \mathrm{~mm}$.

\subsubsection{Leaf surface temperature}

Differences among genotypes in terms of the LST was not significant (Table 3). Various researchers stated that changes in temperature affect plant growth and yield parameters (Olatunji et al., 2016; Kirigia, Winkelmann, Kasili and Mibus, 2018). Also, Hall (2004) stated that long term high temperature leads to unfavorable effects on seed yield in cowpea. Besides, Hesketh (1967) stated that the photosynthesis rate and amount of gas input and output through stomata decrease at high temperatures. However, more studies must be conducted with larger sets of genotypes to understand the tolerance and susceptibility levels in cowpea.

\subsubsection{Total chlorophyll content}

In terms of TCC, statistically significant $(P<0.01)$ differences were determined among genotypes (Table 3). While the highest TCC was obtained from Karagöz, the lowest values obtained from $\mathrm{L}_{3}$ landrace (Table 4). Chlorophyll as one indicator of heatstricken plants is synthesized with ecological and genetic factors and its amount shows diversity for each species (Hendriyani and Setiari, 2009). So, the measurement of chlorophyll content is an indicator of photosynthesis intolerant plants. Higher chlorophyll content in Karagöz shows that its adaptability to heat conditions is superior compared with the other genotypes. Different studies supported the results (Karuwal, Suharsona, Tjahjoleksona and Hanif, 2017). Also, Barro et al. (2018) stated that TCC varied from 42.20 to $62.00 \%$ among the cowpea genotypes with a general mean of $51.38 \%$. 
Table 3

Some agronomic traits of genotypes

\begin{tabular}{lcccc}
\hline Genotypes & $\begin{array}{c}\text { Plant height } \\
(\mathrm{cm})\end{array}$ & $\begin{array}{c}\text { Stem diameter } \\
(\mathrm{mm})\end{array}$ & $\begin{array}{c}\text { Leaf surface temperature } \\
\left({ }^{\circ} \mathrm{C}\right)\end{array}$ & $\begin{array}{c}\text { Total Chlorophyll Content } \\
(\%)\end{array}$ \\
\hline L1 & $62.7 \mathrm{~cd}$ & $4.3 \mathrm{c}$ & 31.7 & $49.1 \mathrm{bc}$ \\
L2 & $54.6 \mathrm{~d}$ & $3.4 \mathrm{~d}$ & 29.1 & $39.0 \mathrm{~d}$ \\
L3 & $57.1 \mathrm{~d}$ & $3.1 \mathrm{~d}$ & 31.6 & $36.3 \mathrm{~d}$ \\
Karn1kara & $68.8 \mathrm{c}$ & $5.1 \mathrm{c}$ & 27.9 & $46.4 \mathrm{c}$ \\
Akk1z & $78.2 \mathrm{~b}$ & $6.1 \mathrm{~b}$ & 30.6 & $51.9 \mathrm{ab}$ \\
Karagöz-86 & $91.3 \mathrm{a}$ & $7.6 \mathrm{a}$ & 30.8 & $56.1 \mathrm{a}$ \\
Mean & 68.8 & 4.9 & 30.3 & 46.5 \\
TUKEY & $28.8^{* *}$ & $2.9^{* *}$ & 17.0 & $14.6^{* *}$ \\
\hline \multicolumn{1}{c}{$(* *: P<0.01)$} & & & &
\end{tabular}

\subsection{Yield components}

The analysis of variances for yield parameters was given in Table 4 . The Results pointed out significant differences among the genotypes on NP, NS and SY.

Table 4

Analysis of variance on three selected yield parameters

\begin{tabular}{lccccccc}
\hline \multirow{2}{*}{ Source of variation } & \multicolumn{3}{c}{ Number of pods per plant } & \multicolumn{2}{c}{ Number of seed per plant } & \multicolumn{3}{c}{$\begin{array}{c}\text { Seed Yield } \\
(\mathrm{kg} / \mathrm{ha})\end{array}$} \\
\cline { 2 - 8 } & DF & MS & F prob. & MS & F prob. & MS & F prob. \\
\hline Genotypes & 5 & 237.5 & $* *$ & 45.8 & $* *$ & 13178868 & $* *$ \\
\hline
\end{tabular}

\subsubsection{Number of pod}

The results showed that genotypes have different pod yield capacity (Table 5). Karagöz had the highest NP (49) while the $\mathrm{L}_{3}$ had the least (25.7). Oladejo, Akinwale and Obisesan (2011) reported NP between 34.78-67.25. The NP is one of the most substantial yield components and it is affected by environmental stress factors such as heat or drought that causes the death of pollen grains and denaturation of physiological tissues (AlAssafi and Abed, 2014; Abed, 2017). It is thought to be caused by genetic differences among genotypes concerning growth potential, nutrient uptake efficiency and yield capacity. Moreover, the adaptability of genotypes also affects yield parameters.

\subsubsection{Number of seed}

The NS changed based on genotypes. The highest NS was found in Karagöz and the lowest one was in $\mathrm{L}_{3}$ (Table 5). Oladejo et al. (2011) pointed out that seed yield changes depending on traits of cultivars and environmental factors. As it is seen in growth and yield parameters, some cowpea genotypes, especially Karagöz and Akkız, showed hopeful performance for the region. It can show the reason for this cowpea grows best in the regions where average temperatures vary between $15-25{ }^{\circ} \mathrm{C}$ and night temperatures should not be less than $15{ }^{\circ} \mathrm{C}$ in growth period (Boukar et al., 2015). So, it is thought that the region is suitable for cowpea cultivation and choosing genotype has a vital role in high yield. Also, it is known that ecological conditions and
According to the results, NP, NS and SY changed between $25.7-41,307.5-684$ and $646-2381 \mathrm{~kg}$ ha', respectively (Table 5 ). The differences among genotypes are thought to be caused by adaptability to heat stress. cultivars have a significant effect on yield parameters. Some researchers stated that yield components change depending on genotypes and their adaptability to the local conditions (Basaran, Ayan, Acar, Mut et al., 2011; Agele, Oyewusi, Fayeun and Famuwagun, 2017). Aliyu, Lawal, Wahab and Ibrahim (2019) stated that NS varied from 22 to 360.

\subsubsection{Seed yield}

A highly significant variation was observed among the test genotypes under investigations (Table 4). The highest seed yield was obtained from Karagöz (2381 kg ha') while the lowest one (646 kg ha') was determined in L3 (Table 5). It is noteworthy that Karagöz variety produced the maximum SY compared to the other varieties. This is so because according to Ogbonnaya et al. (2003), cowpea is recognized to have extreme stomatal control leading to rapid closure of stomata under stress conditions. Also, Reza (2011) stated that seed yield is a polygenic trait. Horn, Shimelis, Sarsu, Mwadzingeni et al. (2018) revealed that genetic diversity affects grain yield both alone and depending on environmental factors. So, it can be understood that while genetic traits of material effect on adaptability to regions, growth parameters, physiological properties, yield components, and it also affect the seed yield, directly or indirectly. Kyei-Boahen, Savala, Chikoye and Abaidoo (2017) denoted that grain yield changed between $1097-1674 \mathrm{~kg} / \mathrm{ha}$ in cowpea depending on various chemical and biological fertilization applications. 
Table 5

Yield and some yield components of genotypes

\begin{tabular}{lccc}
\hline Genotypes & Number of pods per plant & Number of seed per plant & Seed Yield (kg/ha) \\
\hline L1 & $38.6 \mathrm{bc}$ & $478.9 \mathrm{bc}$ & $1599 \mathrm{c}$ \\
L2 & $34.1 \mathrm{c}$ & $422.8 \mathrm{c}$ & $1334 \mathrm{~d}$ \\
L3 & $25.7 \mathrm{~d}$ & $307.5 \mathrm{~d}$ & $646 \mathrm{e}$ \\
Karnikara & $36.6 \mathrm{bc}$ & $478.7 \mathrm{bc}$ & $1514 \mathrm{c}$ \\
Akk1z & $41.0 \mathrm{~b}$ & $559.7 \mathrm{~b}$ & $1850 \mathrm{~b}$ \\
Karagöz-86 & $49.0 \mathrm{a}$ & $684.0 \mathrm{a}$ & $2381 \mathrm{a}$ \\
Mean & 37.5 & 488.6 & 1554 \\
TUKEY & $14.4^{* *}$ & $268.1 * *$ & $437.3 * *$ \\
\hline
\end{tabular}

\subsection{Correlations among agronomic traits in cowpea}

The summary of the correlation coefficients between SY and other traits average is presented in Table 6. The results presented positive and significant correlation was observed among the major of the agronomic traits evaluated. It shows that there were significant positive correlations between SY and NS $(\mathrm{r}=0.98 * *)$, NP $(\mathrm{r}=0.96 * *)$, TCC $(\mathrm{r}=0.93 * *), \mathrm{SD}(\mathrm{r}=0.91 * *)$ and $\mathrm{PH}(\mathrm{r}=0.86)$.

Table 6

The results of correlation analysis between seed yield and other parameters

\begin{tabular}{|c|c|c|c|c|c|c|}
\hline & $\mathrm{PH}$ & SD & LST & TCC & NP & NS \\
\hline $\mathrm{SD}$ & $0.95 * *$ & & & & & \\
\hline LST & 0.04 & -0.05 & & & & \\
\hline $\mathrm{CC}$ & $0.89 * *$ & $0.90 * *$ & 0.03 & & & \\
\hline $\mathrm{NP}$ & $0.86^{* *}$ & $0.88^{* *}$ & -0.06 & $0.92 * *$ & & \\
\hline NS & $0.90 * *$ & $0.93 * *$ & -0.07 & $0.93 * *$ & $0.96 * *$ & \\
\hline SY & $0.86^{* *}$ & $0.91 * *$ & -0.08 & $0.93 * *$ & $0.96 * *$ & $0.98 * *$ \\
\hline
\end{tabular}

(PH: Plant height, SD: Stem diameter, LST: Leaf surface temperature, TCC: Total chlorophyll content, NP: Number of pods per plant, NS: Number of seeds per plant, **: p<0.01)

Otherwise, TCC had a significant correlation with NP $(\mathrm{r}=0.92 * *)$, NS $(\mathrm{r}=0.93 * *)$ and SY $(\mathrm{r}=0.93 * *)$. The well-known role of photosynthesis products on plant growth also affects metabolic activities (Duca, 2015). Several researchers stated that there is a direct positive correlation between TCC and yield parameters (Esaghira et al., 2016; Musa, Bashir and Tadda, 2017; Sozen and Karadavaut, 2018). Besides, SD had a significant correlation with NP $\left(\mathrm{r}=0.88^{* *}\right)$, NS $\left(\mathrm{r}=0.93^{* *}\right)$ and SY $(\mathrm{r}=0.91 * *)$. It can be commented that the plants which have thicker stem diameter are more tolerant of heat conditions exhibited superior performance in terms of yield parameters (El-Naim et al., 2012). Also, a significant correlation was determined between $\mathrm{PH}$ and NP $\left(\mathrm{r}=0.86^{* *}\right)$, NS $\left(\mathrm{r}=0.9^{* *}\right)$, SY $\left(\mathrm{r}=0.86^{* *}\right)$. Walle, Mekbib, Amsalu and Gedil (2018) demonstrated that genetic correlations are more effective than phenotypic correlations in cowpea and it was revealed that $\mathrm{PH}$ has a favorable relationship with yield components.

\section{Conclusion}

From the results obtained in the study, Karagöz exhibited superior properties compared to others in terms of morphological growth, total chlorophyll
It is seed as Table 6, the relationship between NS and SY showed the highest positive correlation $\left(\mathrm{r}=0.98^{* *}\right)$. Besides, NP has the highest correlation after NS. The results are the indicator that NP and NS have a vital role in total grain yield. Various researchers found a high correlation among NP, NS and SY (Alidu, Atokple and Akromah, 2013; Shanko, Andargic and Zelleke, 2014; Patel, Kumar and Meena, 2018). 


\section{References}

Abed RD (2017). Effects of genotypes and potassium rates on some of cowpea traits heritability. Asian Journal of Crop Science 9(1): 11-19. DOI:10.3923/ajcs.2017.11.19

Agbicodo EM, Fatokun CA, Muranaka S, Visser RG F, Van Der Linden CG (2009). Breeding drought tolerant cowpea: Constraints, accomplishments, and future prospects. Euphytica 167: 353-370. https://doi.org/10.1007/s10681-009-9893-8

Agele SO, Oyewusi IK, Fayeun L, Famuwagun IB (2018). Genotype by environment interactions and effects on growth and yield of cowpea varieties in the rainforest and derived savanna agroecologies of Nigeria. International Journal of Plant Breeding and Crop Science 5(2): 370-382.

Al-Assafi RDA, Abed ZA (2014). Selection effectiveness for pods number in early generations of seed yield of cowpea cultivar imported. Iraqi Journal of Agricultural Science 45(8): 909-914.

Al-jubouri HA, Millar PA, Robinson HF (1958). Genotypic and environmental variance and covariance in upland cotton crosses of interspecific origin. Agronomy Journal 50: 633-637.

Alidu MS, Atokple IDK, Akromah R (2013). Genetic analysis of vegetative-stage drought tolerance in cowpea. Greener Journal of Agricultural Science 3: 481-496. DOI:10.15580/GJAS.2013.6.030613516

Aliyu OM, Lawal OO, Wahab AA, Ibrahim UY (2019). Evaluation of advanced breeding lines of cowpea (Vigna unguiculata L. Walp) for high seed yield under farmers' field conditions. Plant Breeding and Biotechnology 7(1): 12-23. https://doi.org/10.9787/PBB.2019.7.1.12

Augustine AJ (2018). Effect of Inter-row and Intrarow spacing on phenological characters of cowpea (Vigna unguiculata L. Walp) varieties in semi-arid region of North-Western Nigeria. Journal of Experimental Agriculture International 27(5): 1-9. DOI:10.9734/JEAI/2018/13986

Barro A, Batieno TBJ, Tignegre JBS, Neya JB, Pale K, Kabore A, Ouedraogo MH, Sawadogo M (2018). Evaluation of agronomic performances of five cowpea lines in the experimental research station of Saria, Burkina Faso. World Journal of Agricultural Research 6(3): 82-86. DOI:10.12691/wjar-6-3-2

Basaran U, Ayan I, Acar Z, Mut H, Asci OO (2011). Seed yield and agronomic parameters of cowpea (Vigna unguiculata L.) genotypes grown in the Black Sea Region of Turkey. African Journal of Biotechnology, 10(62): 13461-13464. DOI:10.5897/AJB11.2489

Bisikwa J, Kawooya R, Ssebuliba JM, Ddungu SP, Biruma M, Okello DK (2014). Effect of plant density on the performance of local and elite cowpea [Vigna unguiculata L. (Walp)] varieties in Eastern Uganda. African Journal of Applied Agricultural Sciences and Technologies 1(1): 2841.

http://www.naroinfohub.org/RepDetails?pn=100 7

Boukar O, Fatokun CA, Roberts PA, Abberton M, Huynh BL, Close TJ, Kyei-Boahen S, Higgins TJV, Ehlers D (2015). Cowpea. In: De Ron, A. M. (ed) Grain Legumes, vol 10, Springer, New York. DOI:10.1007/978-1-4939-2797-5

Daramy MA, Sardoie-Addo J, Dumbuya G (2016). The effects of nitrogen and phosphorus fertilizer application on crude protein, nutrient concentration and nodulation of cowpea in Ghana. Journal of Agricultural and Biological Science 11(12): 470-477.

Dong L, Ravelombola W, Weng Y, Qin J, Bhattarai G, Zia B, Zhou W, Wang Y, Mou B, Shi A (2019). Seedling salt tolerance for above groundrelated traitsin cowpea (Vigna unguiculata (L.) Walp). Euphytica 215(53): 1-22.

Duca M (2015). Plant Physiology. In: Greenbaum EE (ed) Photosynthesis, Springer, New York, pp. 72-80.

Esaghira C, Yamauchi T, Miyamoto Y, Yuasa T, Ishibashi Y, Iwaya-Inoue M (2016). Physiological response of cowpea (Vigna unguiculata (L.) Walp) to drought stress during the pod-filling state. Cryobiology and Cryotechnology 1: 69-75.

El-Naim AM, Jabereldar AA, Ahmed SE, Ismaeil FM, Ibrahim EA (2012). Determination of suitable variety and plants per stand of cowpea (Vigna unguiculata (L) walp.) in the Sandy Soil, Sudan. Advances in Life Science 2(1): 1-5. DOI:10.5923/j.als.20120201.01

Erman M, Çı̆̆ F (2009). Farklı bitki sıklığı uygulamalarının börülce (Vigna unguiculata L.) Walp.)'de verim ve verim ögelerine etkisi. Türkiye VIII. Tarla Bitkileri Kongresi, 19-22 Ekim, Hatay, s. 669-672.

FAO (2018). Cowpea production on the World, Available at: http://www.fao.org/stat

Federal Ministry of Agriculture and Natural Resources (FMANR) (1990). Literature on soil fertility 1nvestigation in Nigeria. Federal Ministry of Agriculture and Natural Resources, Lagos, s. 40.

Freitas ADS, Silva AF, Sampaio EVSB (2012). Yield and biological nitrogen fixation of cowpea varieties in the semi-arid region of Brazil. Biomass and Bioenergy, 45: 109-114. DOI: 10.1016/j.biombioe.2012.05.017

Hall AE (2004). Breeding for adaptation to drought and heat in cowpea. European Journal of Agronomy 21(4): 447-454. 
Hendriyani IS, Setiari N (2009). Chlorophyll content and growth of yard long (Vigna sinensis) at different levels of water supply. Journal of Sains Matematika 17(3): 145-150.

Hesketh JD (1967). Effects of light and temperature during plant growth on subsequent leaf $\mathrm{CO}_{2}$ assimilation rates under standard conditions. Australian Journal of Biological Science 21: 235241.

Horn L, Shimelis H, Sarsu F, Mwadzingeni L, Laing MD (2018). Genotype-by-environment interaction for grain yield among novel cowpea (Vigna unguiculata L.) selections derived by gamma irradiation. The Crop Journal 6(3): 306-313. https://doi.org/10.1016/j.cj.2017.10.002

Kahraman A (2017). Effect of humic acid doses on yield and quality parameters of cowpea [Vigna unguiculata (L.) Walp] cultivars. Legume Rese$\begin{array}{llll}\text { arch } \quad 40 \quad(1): \quad 155-159, \quad \text { DOI: } & \end{array}$ 10.18805/lr.v0iOF.3763.

Karuwal RL, Suharsona S, Tjahjoleksona A, Hanif N (2017). Physiological response of some local cowpea from Southwest Maluku (Indonesia) varieties to drought stress. Biodiversitas 18(4): 1294-1299. DOI:10.13057/biodiv/d180402

Kazai P, Noulas C, Khah E, Vlachostergios D (2019). Yield and seed quality parameters of common bean cultivars grown under water and heat stress field conditions. Agriculture and Food 4(2): 285-302. DOI:10.3934/agrfood.2019.2.285

Kirigia D, Winkelmann T, Kasili R, Mibus H (2018). Development stage, storage temperature and storage duration influence phytonutrient content in cowpea (Vigna unguiculata L. Walp.). Heliyon 4(6): 1-24. DOI:10.1016/j.heliyon.2018.e00656

Korkmaz S, Goksuluk D, Zararsiz G (2014). MVN: An R Package for Assessing Multivariate Normality. The R Journal 6(2): 151-162.

Kyei-Boahen S, Savala CEN, Chikoye D, Abaidoo R (2017). Growth and yield responses of cowpea to inoculation and phosphorus fertilization in different environments. Frontiers in Plant Science 8: 646. DOI:10.3389/fpls.2017.00646

Mangiafico SS (2016). Summary and analysis of extension program evaluation in $\mathrm{R}$ (version 1.18.1). Rutgers Cooperative Extension, New Brunswick.

Makoi JHJR, Chimphango BM, Dakora FD (2009). Effect of legume plant density and mixed culture on symbiotic $\mathrm{N}_{2}$ fixation in five cowpea (Vigna unguiculata L. Walp.) genotypes in South Africa. Symbiosis 48(1-3): 57-67. https://doi.org/10.1007/BF03179985

Massey P, Singh MK, Nautiyal MK, Bhatt L (2020). Evaluation of cowpea (Vigna unguiculata L. Walp) genotypes for yield and associated traits.
International Journal of Chemical Studies 8(1): 1709-1711.

Musa M, Bashir KA, Tadda SA (2017). Response of cowpea (Vigna unguiculata L. Walp) varieties to phosphorus levels in Sudan Savanna of Nigeria. International Multidisciplinary Research Journal 7: 23-29. DOI:10.25081/imrj.2017.v7.3380

Ogbonnaya CI, Sarr B, Brou C, Diouf O, Diop NN, Roy-Macauley H (2003). Selection of cowpea genotypes in hydroponics, pots, and field for drought tolerance. Crop Science 43(3): 11141120 .

Oladejo AS, Akinwale RO, Obisesan IO (2011). Interrelationships between grain yield and other physiological traits of cowpea cultivars. African Crop Science Journal 19(3): 189-200.

Olatunji OA, Okunlola GO, Komolafe ET, Afolabi AM, Tariq A, Odeleye AA (2016). Yield and growth characteristics of cowpea (Vigna unguiculata) as affected by prior heat stress and nutrient addition. African Journal of Agricultural Research 11(43): 4269-4276. DOI:10.5897/AJAR2016.11651

Patel PS, Kumar P, Meena R (2018). Correlation and Path analysis in Cowpea [(Vigna unguiculata (L.) Walp.)]. International Journal of Pure and Applied Bioscience 6(5): 142-146. DOI:http://dx.doi.org/10.18782/2320-6941

Ravelombola W, Shi A, Qin J, Weng Y, Bhattarai G, Zia B, Zhou W, Mou B (2018). Investigation on various aboveground traits to identify drought tolerance in cowpea seedlings. Hortscience 53(12): 1757-1765.

https://doi.org/10.21273/HORTSCI13278-18

Reza GA (2011). Assessment of relationship between seed and oil yield with agronomic traits in spring safflower cultivars under drought stress condition. Journal of Research in Agricultural Science 7(2): 109-113.

Sert H, Ceyhan E (2012). Hatay ili ekolojik şartlarında börülce (Vigna sinensis (1.) savi) çeşitlerinin tane verimi ve bazı tarımsal özellikleri üzerine farklı bitki sıklıklarının etkileri. Selçuk Tarım ve Glda Bilimleri Dergisi, 26(1): 34-43.

Sanchez-Navarro V, Zornoza R., Faz A, Fernandez JA (2019). Does the use of cowpea in rotation with a vegetable crop improve soil quality and crop yield and quality? A field study in SE Spain. European Journal of Agronomy 107: 1017. https://doi.org/10.1016/j.eja.2019.03.007

Shanko D, Andargic M, Zelleke H (2014). Interrelationship and path coefficient analysis of some growth and yield characteristics in cowpea (Vigna unguiculata L. Walp) genotypes. Journal of $\begin{array}{ll}\text { Plant } \quad \text { Science } 2(2): & \text { 97-101. }\end{array}$ DOI:10.11648/j.jps.20140202.13

Simion T (2018). Adaptability performances of cowpea [Vigna unguiculata (L.) Walp] genoty- 
pes in Ethiopia. Food Science and Quality Management 72: 43-47.

Simunji S, Munyinda KL, Lungu OI, Mweetwa AM, Phiri E (2019). Evaluation of cowpea (Vigna unguiculata L.walp) genotypes for biological nitrogen fixation in maize-cowpea crop rotation. Sustainable Agriculture Research 8(1): 82-93. DOI:10.5539/sar.v8n1p82

Sozen O, Karadavut U (2017). Determination of direct and indirect relations between some yield characters of red lentil cultivars. Pakistan Journal of Botany, 49(6): 2339-2346.

Sozen O, Karadavut U (2018). Correlation and path analysis for yield performance and yield components of chickpea (Cicer arietinum L.) genotypes cultivated in Central Anatolia. Pakistan Journal of Botany, 50(2): 625-633.

Stancheva I, Nedyalkova K, Geneva M, Donkova R, Hristozkova M, Perfanova I, Sichanova M, Petkova G, Djonova E, Valchovski H (2016). Nutritional value of cowpea (Vigna Unguiculata L. Walp) grain grown under different soil moisture as affected to the dual inoculation with nitrogen fixing bacteria and arbuscular mycorrhizal fungi. Bulgarian Journal of Soil Science 1(2): 112-121.
Stoilova T, Pereira G, Sousa MMT, Carnide V (2005). Diversity in common bean landraces (Phaseolus vulgaris L.) from Bulgaria and Portugal. Journal of Central European Agriculture 6(4): 443-448.

TUIK (2018). Harvested area for cowpea in Turkey. Available at: http://www.tuik.gov.tr/UstMenu.do?metod=teme list

Verbree DA, Singh, BB, Payne WA (2015). Genetics and heritability of shoot drought tolerance in cowpea seedlings. Crop Science 55(1): 146153. DOI:10.2135/cropsci2014.02.0137.

Walle T, Mekbib F, Amsalu B, Gedil M (2018). Correlation and path coefficient analyses of cowpea (Vigna unguiculata L.) landraces in Ethiopia. American Journal of Plant Science 9: 2794-2812. DOI:10.4236/ajps.2018.913202

Yu L, Wang W, Xin Z, Zheng W (2016). A review on leaf temperature sensor: measurement methods and application. International conference on computer and computing technologies in agriculture, 12-15 August, Springer, China, pp. 1-15. DOI:1010.1007/978-3-319-48357-3_21 